\title{
BANKALARIN TÜREV ÜRÜN KULLANIMINI BELİRLEYEN FİNANSAL VE MAKROEKONOMIKK FAKTÖRLER ${ }^{1}$
}

\section{FINANCIAL AND MACROECONOMIC FACTORS DETERMINING THE USE OF DERIVATIVE PRODUCTS BY BANKS}

\author{
Ersin YENISU (D) Z Zeynep TIRAŞ iD ** Oğuz SAYGIN (D)***
}

Araștırma Makalesi / Geliş Tarihi: 31.07.2021

Kabul Tarihi: 30.09 .2021

$\ddot{\mathbf{O} z}$

Finansal piyasalarda türev ürün kullanımının amacı riski transfer etmek ya da riski yönetmektir. Türev araçlar özellikle son yıllarda finans sektöründe yoğunlukla kullanılmaya başlanmıştır. Türkiye'de ise finansal sistemin en önemli unsuru olan bankalar da fon yönetiminde türev ürün kullanımını arttırmışlardır. Dolayısıyla türev ürün kullanımını belirleyen faktörlerin tespit edilmesi bankacılık sektörü için önem kazanmıştır. $\mathrm{Bu}$ doğrultuda çalışmanın amacı Türkiye'de bankaların gerçekleştirdikleri türev piyasa işlemlerinin hangi finansal ve makroekonomik değişkenlerle ilişkili olduğunu belirlemektir. Bu amaç doğrultusunda çalışmada kullanılan yöntemler korelasyon analizi ve ARDL sınır testidir. Analizde incelenen dönem ise aylık verilerden oluşan 2005:1-2021:2'dir. Yapılan tahminlere göre bankalar özellikle aktif büyüklüğü arttıkça türev araç kullanımını arttırmaktayken; risk (finansal risk ve döviz kuru riski) arttıkça da türev araç kullanımı artmaktadır. Diğer taraftan türev araç kullanımı arttıkça bankaların öz sermaye karlılı̆̆ da azalmaktadır. Bunun sebebi ise yatırılan sermayenin alternatif maliyeti olabilir.

Anahtar Kelimeler: Türev Ürünler, Finansal ve Makroekonomik Değişkenler, ARDL Sınır Testi

JEL Sinıflaması: C01, G21, O10

\begin{abstract}
The purpose of invest in derivatives in financial markets is to transfer or manage risk. Especially in recent years, derivative instruments have been invested extensively in the financial sector. In Turkey, banks, which are the most important component of the financial system, have also increased the investment of derivatives in fund management. Therefore, determining the factors affecting the investment of derivatives has gained importance for the banking sector. In this direction, the aim of the study is to determine which financial and macroeconomic variables are related to the derivative market transactions performed by banks in Turkey. For this purpose, the methods used in the study are correlation analysis and ARDL boundary test. The period examined in the analysis is 2005:1-2021:2, employed monthly data. According to the estimations, even as banks increase the investment of derivative instruments especially when their asset size increases; when the risk (financial risk and exchange rate risk) increases, the investment of derivative instruments increases. On the other hand, as the investment of derivative instruments increases, the return on equity of banks also decreases. The reason for this finding may be the alternative cost of invested capital.
\end{abstract}

Keywords: Derivative Products, Financial and Macroeconomic Variables, ARDL Bound Testing

JEL Classification: C01, G21, O10

\footnotetext{
${ }^{1}$ Bibliyografik Bilgi (APA): FESA Dergisi, 2021; 6(3) ,530-544 / DOI: 10.29106/fesa.977060

*Nevşehir Hacı Bektaş Veli Üniversitesi İşletme Doktora Öğrencisi, ersinyenisu@gmail.com, Ankara - Türkiye, ORCID: 0000-0002-0235-4270

${ }^{* *}$ Nevşehir Hacı Bektaş Veli Üniversitesi İşletme Doktora Öğrencisi, zeyneptiras95@gmail.com, Kırşehir Türkiye, ORCID: 0000-0003-1873-7003

${ }^{* * *}$ Dr. Öğr. Üyesi, Nevşehir Hacı Bektaş Veli Üniversitesi Meslek Yüksekokulu, osaygin@nevsehir.edu.tr, Nevşehir - Türkiye, ORCID: 0000-0002-0272-5553
} 


\section{Giriş}

Risk yönetimi modern ekonomilerde son derece önemli bir yere sahiptir. Bununla birlikte geleneksel finansal araçların analizinde risk ve getiri ilişsisi geçmişten günümüze gerek akademik çevrelerde gerekse uygulamada dikkat çeken bir konu olmuştur. Finansal teknolojilerin hızla geliştiği günümüzde ise riski paylaşmak, riski transfer etmek ya da daha genel anlamıyla riski yönetmek önem kazanmıştır. Türev araçlar, özellikle finansal kuruluşların risk değerlendirmesinde öne çıkan çağdaş bir enstrüman haline gelmiştir. Bu doğrultuda çalışmanın amacı, Türkiye'de finansal sistemin omurgası olan bankaların türev ürün kullanımını etkileyen değişkenleri tespit etmektir.

Türev araçlar uluslararası faaliyetlerde önemli bir rol oynamaktadır. Daha önceki yayınlar kapsamında Güven (2019) çalışmasında şirketlerin türev işlem hacimleri ile ihracat tutarları arasındaki ilişkileri incelemiştir. Bununla birlikte çok farklı boyutlarıyla ele alınan türev araçlar konusunu Çankaya ve Güçver (2019) işletme yaşı ya da diğer bir deyişle kurumsallaşma boyutuyla ele almışlardır. Diğer taraftan Takao ve Lantara (2010) şirketlerde türev araç kullanımını etkileyen finansal ve ekonomik değişkenler konusunu araştırmışlardır. Benzer şekilde Chickwira vd. (2021) çalışmalarında bankaların türev araç kullanımı ile finansal ve makroekonomik değişkenler ilişsisini incelemişlerdir. Bu çalışmada da bankaların türev ürün kullanım hacmini etkileyen finansal ve makroekonomik değişkenler tespit edilmeye çalışılmıştır. Çalışmanın literatürden temel farklılığı analizlerde kullanılan değişkenlerin literatürdekilerden farklı bir kombinasyonun yine farklı bir yöntemle analiz edilmiş olmasıdır. Buna ek olarak bu çalışma bankaların türev araç kullanımını etkileyen değiş̧kenleri saptaması açısından karar vericiler için önemlidir.

Çalışmanın izleyen bölümünde türev ürünler başlığı altında türev araçlar ve türev piyasalar hakkında bilgi verilmeye çalışılmıştır. Üçüncü bölüm yerli ve yabancı literatür incelemesine ayrılmıştır. Çalışmanın bir sonraki bölümünde ise metodolojiye değinilmiş ve analizlerde kullanılan veriler hakkında bilgi sunulmuştur. Bir sonraki bölümde de uygulama gerçekleştirilmiş ve bulgular özetlenmeye çalışılımıştır. Çalışma genel değerlendirmenin yer aldığı sonuç bölümüyle sonlandırılmıştır.

\section{Türev Ürünler}

Türev ürünler bir dayanak varlık üzerine yazılmış olan ve risk yönetimi amacıyla kullanılan finansal enstrümanlardır. Türev piyasalar ise türev ürünlerle ilgili işlemlerin gerçekleştirildiği ve türev araçların alım satımının yapıldığı vadeli piyasalardır. Günümüzde türev piyasalarda çok büyük hacimli işlemler yapılmakta ve bu nedenle türev işlemler dünya finans piyasalarında belirleyici rol oynamaktadır (Chamber, 2007; s. 1).

Tarihsel olarak değerlendirildiğinde 1970'li yıllarda dünya ekonomisinde yaşanan petrol şoklarıyla Bretton Woods sistemi çökmüştür. Dünya ekonomisindeki söz konusu gelişmelerden sonra uluslararası piyasalarda faiz, fiyat ve kur riskleri ortaya çıkmıştır. Aslında Eski Yunan'dan bu yana bilinen ve kullanılan türev araçlar özellikle 1980'li yıllardan sonra risk yönetimi amacıyla dünyada kullanılmaya başlanmıştır. Türkiye'de ise özellikle 2000'li yıllardan sonra türev işlemlerin gerçekleştirildiği bilinmektedir. Temel fonksiyonları risk yönetimi ve geleceğe yönelik fiyat keşfi olan türev ürünler forward, futures, opsiyon ve swap'tan oluşmaktadır (Ceylan ve Korkmaz, 2018; s. 611-613).

Türev işlemlerin veya vadeli işlem piyasalarının ilk kurumsal örneği ise Amerika Birleşik Devletleri'nde 1840'lı yıllarda kurulan Chicago Board of Trade (CBOT)'dir. Bir tahıl borsası olarak kurulan bu borsanın amacı çok büyük hacimli işlemler gerçekleştiren tüccarların arz talep dengesizliğinden zarar görmelerini önlemek olmuştur. $\mathrm{Bu}$ borsada tahılın yanı sıra çok sayıda ürünün ticarete konu olmasıyla 1919 yılında Chicago Emtia Borsası (Chicago Mercantile Exchange - CME) kurulmuştur. Söz konusu borsa kuruluşundan günümüze faaliyettedir (Çakır, 2008; s. 3).

Dünya piyasalarında türev işlem hacminin artışının ardında yatan temel sebep ise finansal krizlerdir. Bankalar ve diğer finans kuruluşları karşılaş̧ıkları finansal risklerden korunmak ve gelecekte görülebilecek muhtemel riskleri yönetebilmek amacıyla türev piyasa işlemlerine başvurmuşlardır (Çonkar ve Ata, 2002; s. 1-17). Bu doğrultuda günümüzde Türkiye'de finansal sistemin omurgası durumunda olan bankalar risk yönetimi amacıyla türev işlemlere özel bir önem vermektedirler.

Kısacası, finansal piyasalar açısından türev ürünler en modern finansal araçlardandır. Nitekim günümüzde gelişmiş ülkelerde artan işlem hacminin yanı sıra çeşitli varyasyonlara dayalı oluşturulan türev araç sayısının da her geçen gün arttığı bilinmektedir. Türkiye gibi gelişmekte olan ülkeler ise bu değişen finansal sisteme entegre olmaya devam etmektedirler. 


\section{Literatür Taraması}

Literatürde türev araçlar üzerine yapılan çalışmalar çok eskilere dayanmamaktadır. Bu alandaki uygulamalı çalışmaların dünyada $1990^{\prime}$ 'l yıllardan itibaren Türkiye'de ise 2000'li yıllardan sonra giderek yoğunlaştı̆̆ görülmektedir. Tablo 1'de özellikle bankaların ve finansal piyasalarda faaliyet gösteren diğer sektör şirketlerinin türev ürün kullanımını inceleyen Türkçe literatürden örnekler sunulmuştur.

Tablo 1: Türev Ürün Kullanımı Üzerine Yapılan Ulusal Çalışmalar

\begin{tabular}{|c|c|c|c|c|}
\hline Yazar (Tarih) & Ülke & Yöntem & Dönem & Sonuç/Bulgular \\
\hline Demir (2009) & Türkiye & $\begin{array}{l}\text { Lojistik } \\
\text { Regresyon }\end{array}$ & 2006 & $\begin{array}{l}\text { Döviz açık pozisyonu ile döviz türev ürün } \\
\text { kullanımı arasında anlamlı bir ilişki vardır. }\end{array}$ \\
\hline Dündar (2011) & Türkiye & Tobit Model & 2011 & $\begin{array}{l}\text { Firma büyüklüğü ve ihracat düzeyi arttıç̧a } \\
\text { türev ürün kullanımı artmakta, dövizle } \\
\text { borçlanma arttıkça türev ürün kullanımı } \\
\text { azalmaktadır. }\end{array}$ \\
\hline $\begin{array}{l}\text { Anbar ve Alper } \\
\qquad(2011)\end{array}$ & Türkiye & $\begin{array}{l}\text { Tobit Regresyon } \\
\text { Analizi }\end{array}$ & $1999-2010$ & $\begin{array}{l}\text { Öz sermaye karlılığı ve net faiz marjının } \\
\text { türev ürün kullanım yoğunluğuyla pozifif } \\
\text { ilişkili olduğu bulgulanmışıtır. Aktif } \\
\text { büyüklüğü, karşılıklar ve faiz oranları ile } \\
\text { türev ürün kullanım yoğunluğu arasında ise } \\
\text { ters yönlü ilişki vardır. }\end{array}$ \\
\hline $\begin{array}{l}\text { Bayrakdaroğlu } \\
\text { vd. (2013) }\end{array}$ & Türkiye & $\begin{array}{l}\text { Tek Yönlü } \\
\text { Varyans Analizi } \\
\text { (One-way } \\
\text { ANOVA) }\end{array}$ & 2013 & $\begin{array}{l}\text { Büyük işletmelerin daha ziyade spekülatif } \\
\text { amaçlı türev ürün kullandıkları görülmüştür. } \\
\text { Şirketler genel olarak türev araçlardan } \\
\text { haberdar olmalarına rağmen türev ürün } \\
\text { kullanımında isteksizdirler. }\end{array}$ \\
\hline $\begin{array}{l}\text { Özgümüş vd, } \\
\text { (2013) }\end{array}$ & Türkiye & $\begin{array}{l}\text { Regresyon } \\
\text { Analizi, GARCH- } \\
\text { EGARCH }\end{array}$ & $\begin{array}{l}\text { 2005M2- } \\
2011 \mathrm{M} 11\end{array}$ & $\begin{array}{l}\text { Farklı makroekonomik değişkenlerin vadeli } \\
\text { işlem sözleşmelerinin getirileri, işlem } \\
\text { hacimleri ve volatiliteleri üzerinde farklı } \\
\text { etkileri bulunmaktadır. }\end{array}$ \\
\hline Doğan (2013) & Türkiye & Logit Model & 2011-2012 & $\begin{array}{l}\text { Firma büyüklüğü ve kurumsal yönetim } \\
\text { endeksine dâhil olma türev ürün kullanımı } \\
\text { etkilemektedir. }\end{array}$ \\
\hline $\begin{array}{l}\text { Tanrı̈̈ven ve } \\
\text { Yenice (2014) }\end{array}$ & Türkiye & $\begin{array}{l}\text { Eşbütünleşme } \\
\text { Analizi }\end{array}$ & $\begin{array}{l}\text { 2002Q4- } \\
\text { 2014Q1 }\end{array}$ & $\begin{array}{l}\text { Türev araç kullanımı arttıkça hem risklilik } \\
\text { hem de karlılık artmaktadır. Fakat risklilik } \\
\text { karlılığa göre daha fazla artış göstermektedir. }\end{array}$ \\
\hline Şimşek (2015) & Türkiye & $\begin{array}{l}\text { Regresyon } \\
\text { Analizi, Granger } \\
\text { Nedensellik, } \\
\text { VAR Analizi }\end{array}$ & $\begin{array}{l}\text { 2006M1- } \\
2014 \mathrm{M} 10\end{array}$ & $\begin{array}{l}\text { Bankalarda; piyasa riski, TL mevduatı, } \\
\text { bilanço dışı riskler, TCMB rezervleri ve } \\
\text { enflasyon ile döviz swap işlemleri arasında } \\
\text { istatistiksel açıdan anlamlı ilişki vardır. }\end{array}$ \\
\hline Yalçın (2015) & Türkiye & $\begin{array}{l}\text { Genellelştirilmiş } \\
\text { Doğrusal Model } \\
\text { (GMM) }\end{array}$ & 2004-2014 & $\begin{array}{l}\text { Türev ürün kullanımı ile enflasyon ve } \\
\text { bilanço toplamı ile pozitif; sermaye } \\
\text { yeterliliği, net kar ve bilanço içi faiz riski ile } \\
\text { negatif ilişki vardır. }\end{array}$ \\
\hline $\begin{array}{l}\text { Boztosun vd. } \\
\quad(2016)\end{array}$ & Türkiye & $\begin{array}{l}\text { Lojistik } \\
\text { Regresyon }\end{array}$ & 2016 & $\begin{array}{l}\text { Türev ürün kullanımını işletme } \\
\text { (operasyonel) riski ve firmanın yurt dış1 } \\
\text { yatırım varlığı belirlemektedir. }\end{array}$ \\
\hline Durmuş (2016) & Türkiye & Panel EKK & 2007-2014 & $\begin{array}{l}\text { Şirket büyüklüğü, büyüme firsatları, } \\
\text { kurumsallık, finansal sıkıntı, faiz riski ve } \\
\text { döviz riski arttıkça türev ürün kullanımı }\end{array}$ \\
\hline
\end{tabular}




\begin{tabular}{|c|c|c|c|c|}
\hline & & & & $\begin{array}{l}\text { artmaktadır. Karlılık ile döviz türev ürün } \\
\text { kullanımı arasında ters yönlü ilişki vardır. }\end{array}$ \\
\hline $\begin{array}{l}\text { Oktar ve Yüksel } \\
\qquad(2016)\end{array}$ & Türkiye & MARS Yöntemi & $\begin{array}{l}\text { 2003Q1- } \\
\text { 2015Q3 }\end{array}$ & $\begin{array}{l}\text { Bankaların ayırdığı özel karşılıklar ile türev } \\
\text { ürün kullanımı arasında negatif yönlü bir } \\
\text { ilisski vardır. Diğer taraftan bankalar takipteki } \\
\text { kredi oranı arttıkça türev araç kullanımını } \\
\text { arttırarak riski yönetmeye çalışmaktadırlar. }\end{array}$ \\
\hline Güngör (2017) & Türkiye & $\begin{array}{l}\text { Logit ve Tobit } \\
\text { Modeller }\end{array}$ & 2015 & $\begin{array}{l}\text { Her iki modele göre firma büyüklüğü, dış } \\
\text { satıslar ve yabancı borç oranı türev ürün } \\
\text { kullanımı olumlu etkilemekte; varlıkların } \\
\text { getirisi (ROA) ve likidite türev ürün } \\
\text { kullanımını olumsuz etkilemektedir. }\end{array}$ \\
\hline $\begin{array}{l}\text { Şirvan ve Alp } \\
\quad(2017)\end{array}$ & Türkiye & $\begin{array}{l}\text { Panel Regresyon } \\
\text { Analizi, } \\
\text { Eşbütünleşme }\end{array}$ & $\begin{array}{l}\text { 2007Q1- } \\
\text { 2015Q4 }\end{array}$ & $\begin{array}{l}\text { Türev araçlar ile kredi riski, piyasa riski ve } \\
\text { sermaye yeterlilik rasyosu arasında yeterli } \\
\text { düzeyde ilişki bulunmamaktadır. }\end{array}$ \\
\hline $\begin{array}{l}\text { Fettahoğlu vd. } \\
\quad(2018)\end{array}$ & Türkiye & $\begin{array}{l}\text { Veri Zarflama } \\
\text { Analizi, } \\
\text { Regresyon, } \\
\text { Yapay Sinir } \\
\text { Ağları ve } \\
\text { ANOVA }\end{array}$ & 2011-2014 & $\begin{array}{l}\text { Sermaye yeterliliği yüksek olan bankaların } \\
\text { daha az türev ürün kullandığ } 1 \text {, sermaye } \\
\text { yeterliliği düsük olan bankaların ise daha } \\
\text { fazla türev ürün kullandığ görülmüştür. }\end{array}$ \\
\hline Efeoğlu (2018) & Türkiye & $\begin{array}{l}\text { Panel Veri } \\
\text { Analizi }\end{array}$ & $2010-2014$ & $\begin{array}{l}\text { Tobin Q oranı ile türev ürün kullanımı } \\
\text { arasında pozitif ilişki vardır. }\end{array}$ \\
\hline $\begin{array}{l}\text { Çankaya ve } \\
\text { Güçver (2019) }\end{array}$ & Türkiye & $\begin{array}{l}\text { Panel Lojistik } \\
\text { Regresyon }\end{array}$ & $2007-2016$ & $\begin{array}{l}\text { Türev ürün kullanımı ile aktif büyüklüğü, } \\
\text { likidite oranı, kaldıraç oranı, finansal } \\
\text { borçluluğun toplam borçlanmaya oranı, } \\
\text { piyasa değeri, yurtdışı satışların toplam } \\
\text { satışlara oranı, vergi ödemelerinin net } \\
\text { karlılığa oranı ve kurumsal yönetim } \\
\text { endeksine dâhil olma değişkeni arasında } \\
\text { anlamlı ilişki vardır. }\end{array}$ \\
\hline $\begin{array}{c}\text { Akkaynak ve } \\
\text { Y1ldırım (2019) }\end{array}$ & Türkiye & $\begin{array}{l}\text { Panel Regresyon } \\
\text { Analizi }\end{array}$ & $\begin{array}{l}\text { 2012Q1- } \\
\text { 2017Q4 }\end{array}$ & $\begin{array}{l}\text { Bankaların aktiflerinde yer alan türev ürün } \\
\text { varlığı risk ve karlılık üzerinde negatif etkiye } \\
\text { sahiptir. }\end{array}$ \\
\hline $\begin{array}{l}\text { Kuzu ve Çelik } \\
\text { (2019) }\end{array}$ & Türkiye & $\begin{array}{l}\text { Panel Veri } \\
\text { Analizi }\end{array}$ & $2010-2018$ & $\begin{array}{l}\text { Bilanço dışı riskler, enflasyon ve bankaların } \\
\text { TL mevduatları döviz swap kullanımını } \\
\text { negatif etkilemekte; piyasa riski ve kur riski } \\
\text { pozitif etkilemektedir, Faiz oranı ile döviz } \\
\text { swap işlemleri arasında ise istatistiksel } \\
\text { açıdan anlamlı bir ilişki bulunamamıştır. }\end{array}$ \\
\hline $\begin{array}{c}\text { Durmuş ve } \\
\text { Coşkun (2019) }\end{array}$ & Türkiye & Panel EKK & $2007-2014$ & $\begin{array}{l}\text { Türev ürün kullanımı düzeyini belirleyen } \\
\text { faktörler şirket büyüklüğ̈ü, finansal sıkınt } \\
\text { olasılığı, uzun vadeli borçlanma seviyesi, } \\
\text { döviz kuru riski, faiz oranı riski ve büyüme } \\
\text { fırsatlarıdır. }\end{array}$ \\
\hline Güven (2019) & Türkiye & $\begin{array}{l}\text { Çoku Doğrusal } \\
\text { Regresyon ve } \\
\text { Lojistik } \\
\text { Regresyon }\end{array}$ & 2017 & $\begin{array}{l}\text { Firma büyüklüğü, döviz borcu, ihracat, } \\
\text { kurumsallaşma (firma yaşı) ve likidite oranı } \\
\text { ile türev ürün kullanımı arasında anlamlı bir } \\
\text { ilişki vardır. }\end{array}$ \\
\hline Sefertaş (2020) & Türkiye & $\begin{array}{l}\text { Regresyon ve } \\
\text { ANOVA }\end{array}$ & $2008-2017$ & $\begin{array}{lcl}\text { Bankaların türev ürün kullanımı aktif } \\
\text { büyüklüğü, } \\
\text { kredi/mevduat oranı, }\end{array}$ \\
\hline
\end{tabular}




\begin{tabular}{|c|c|c|c|c|}
\hline & & & & $\begin{array}{l}\text { kalitesi ve yabanc1 } \\
\text { etkilemektedir. }\end{array}$ \\
\hline Taştemel (2020) & Türkiye & $\begin{array}{l}\text { Yüzde/Oran } \\
\text { Analizi }\end{array}$ & 2015-2019 & $\begin{array}{l}\text { Türkiye'de bankalar genellikle alım-satım } \\
\text { amaçlı türev ürün kullanmaktadırlar. } \\
\text { Bununla birlikte her yıl türev ürün kullanım } \\
\text { hacmi artmaktadır, Türev piyasa } \\
\text { işlemlerinde en büyük pay sahibi ise swap } \\
\text { işlemleridir. }\end{array}$ \\
\hline $\begin{array}{l}\text { Akkaya ve } \\
\text { Torun }(2020)\end{array}$ & Türkiye & $\begin{array}{l}\text { Korelasyon, } \\
\text { Johansen } \\
\text { Eşbütünleşme, } \\
\text { VECM }\end{array}$ & $2002-2018$ & $\begin{array}{l}\text { Türev ürün kullanımı ile ortalama öz kaynak } \\
\text { karlılığı ve sermaye yeterlilik oranı arasında } \\
\text { eşbütünleşme ilişkisine rastlanılmıştır. }\end{array}$ \\
\hline $\begin{array}{c}\text { Akarsu ve } \\
\text { Alacahan }(2020)\end{array}$ & Türkiye & $\begin{array}{l}\text { Doğrusal } \\
\text { Regresyon } \\
\text { Analizi }\end{array}$ & $\begin{array}{l}\text { 2014M1- } \\
\text { 2020M6 }\end{array}$ & $\begin{array}{l}\text { Bankalarda türev ürün kullanımı ile TL } \\
\text { mevduatı, TL/USD dolar kuru ve mevduat } \\
\text { faiz oranları arasında pozitif yönlü ilişki } \\
\text { gözlemlenmiştir. }\end{array}$ \\
\hline
\end{tabular}

Tablo 1'den türev ürün kullanımını inceleyen çalıșmalarda çok farklı finansal ya da ekonomik değișkenlerin kullanıldığı ve yine analizlerde çok farklı yöntemlerin kullanıldığı görülmektedir. Türkiye bankacılık sektörü örneğini ele alan bu çalışmada ise değişkenler arasındaki eşbütünleşme ilişkisini açıklayan ARDL sınır testi kullanılmıştır. Bu yönüyle çalışmanın literatüre katkıda bulunacağı öngörülmektedir.

Tablo 2: Türev Ürün Kullanımı Üzerine Yapılan Uluslararası Çalışmalar

\begin{tabular}{|c|c|c|c|c|}
\hline Yazar (Tarih) & Ülke & Yöntem & Dönem & Sonuç/Bulgular \\
\hline $\begin{array}{l}\text { Ahmed vd. } \\
\text { (1997) }\end{array}$ & $\mathrm{ABD}$ & $\begin{array}{l}\text { Panel Veri } \\
\text { Analizi }\end{array}$ & 1994 & $\begin{array}{l}\text { Türev ürün kullanan ticari bankalar daha az } \\
\text { faiz oranı riski taşımaktadırlar. }\end{array}$ \\
\hline $\begin{array}{c}\text { Carter and } \\
\text { Sinkey (1998) }\end{array}$ & $\mathrm{ABD}$ & $\begin{array}{l}\text { Probit Model } \\
\quad(\text { Panel) }\end{array}$ & $1990-1993$ & $\begin{array}{l}\text { İşletme büyüklüğü ile türev ürün kullanımı } \\
\text { arasında bir ilişki yoktur. Faiz riski arttıkça } \\
\text { türev ürün kullanımı artmaktadır. }\end{array}$ \\
\hline $\begin{array}{l}\text { Golberg vd } \\
\text { (1998) }\end{array}$ & $\mathrm{ABD}$ & $\begin{array}{l}\text { Probit Model, } \\
\text { Kesilmiş } \\
\text { (Truncated) Panel } \\
\text { Model, EKK, } \\
\text { Tobit Model }\end{array}$ & 1993 & $\begin{array}{l}\text { Çok uluslaşma arttıkça, büyüme firsatları } \\
\text { geliştikçe ve kaldıraç düzeyi yükseldikçe } \\
\text { türev ürün kullanımı artmaktadır. }\end{array}$ \\
\hline Nieto vd, (1998) & İspanya & $\begin{array}{l}\text { Johansen } \\
\text { Eşbütünleşme, } \\
\text { Granger } \\
\text { Nedensellik }\end{array}$ & 1994-1996 & $\begin{array}{l}\text { Future sözleşme hacmi ile borsa endeksi } \\
\text { eşbütünleşiktir. Borsa endeksi yükseldikçe } \\
\text { future sözleşme sayısı da artmaktadır. }\end{array}$ \\
\hline $\begin{array}{l}\text { Hundman } \\
\text { (1999) }\end{array}$ & $\mathrm{ABD}$ & $\begin{array}{l}\text { Havuzlanmış } \\
\text { Zaman Serisi }\end{array}$ & $1995-1997$ & $\begin{array}{l}\text { Türev ürün kullanımı ile banka büyüklüğü ve } \\
\text { sermaye yeterliliği arasında pozitif yönlü, net } \\
\text { faiz marjı ile negatif yönlü ilişki vardır. }\end{array}$ \\
\hline Kim vd. (2004) & $\begin{array}{l}\text { ABD ve } \\
\text { Hollanda }\end{array}$ & $\begin{array}{l}\text { Panel Veri } \\
\text { Analizi }\end{array}$ & 1996-2002 & $\begin{array}{l}\text { Hisse senedi fiyat volatilitesi ile her iki } \\
\text { kontrat sayısı arasında çift yönlü nedensellik } \\
\text { vardır. }\end{array}$ \\
\hline Shiu (2007) & $\begin{array}{l}\text { Birleşik } \\
\text { Krallık }\end{array}$ & $\begin{array}{l}\text { Panel Veri } \\
\text { Analizi }\end{array}$ & 1994-2002 & $\begin{array}{l}\text { Firma büyüklüğü, likidite ve faiz oranı } \\
\text { riskine maruz kalma düzeyi ile türev ürün } \\
\text { kullanım miktarı arasında ilişki vardır. }\end{array}$ \\
\hline $\begin{array}{l}\text { Purnanandam } \\
\quad(2007)\end{array}$ & $\mathrm{ABD}$ & $\begin{array}{c}\text { Panel Veri } \\
\text { Analizi }\end{array}$ & $1980-2003$ & $\begin{array}{l}\text { Türev ürün kullanan ticari bankalar } \\
\text { kullanmayanlara göre para politikas1 } \\
\text { şoklarına daha az maruz kalmaktadırlar. }\end{array}$ \\
\hline
\end{tabular}




\begin{tabular}{|c|c|c|c|c|}
\hline $\begin{array}{l}\text { Adkins vd. } \\
\quad(2007)\end{array}$ & $\mathrm{ABD}$ & Probit Model & $1996-2000$ & $\begin{array}{l}\text { Yöneticilere verilen opsiyon ödüllerinin } \\
\text { yüksek olduğu bankalarda türev ürün } \\
\text { kullanımı azalmaktayken, kurumsal yönetim } \\
\text { düzeyi arttıkça türev ürün kullanımı } \\
\text { artmaktadır. }\end{array}$ \\
\hline $\begin{array}{l}\text { Ashraf vd. } \\
\text { (2007) }\end{array}$ & $\mathrm{ABD}$ & $\begin{array}{l}\text { Korelasyon ve } \\
\text { Regresyon }\end{array}$ & $1997-2004$ & $\begin{array}{l}\text { Bankaların türev ürün kullanma eğilimleri } \\
\text { yönetim yapısından ziyade risk yönetim } \\
\text { stratejilerine bağlıdır. }\end{array}$ \\
\hline $\begin{array}{l}\text { Hassan and } \\
\text { Khasawneh } \\
\quad(2009)\end{array}$ & ABD & $\begin{array}{l}\text { Lojistik Difüzyon } \\
\text { Modeli }\end{array}$ & $1992-2008$ & $\begin{array}{l}\text { Türev araç kullanımı bankaların sermaye } \\
\text { yeterliliğinden, ekonomik konjonktürden ve } \\
\text { ekonomik koşullardan etkilenmemektedir. }\end{array}$ \\
\hline $\begin{array}{l}\text { Bartram vd. } \\
\quad(2009)\end{array}$ & $\begin{array}{l}\text { Uluslararas1 } \\
\text { (7467 firma) }\end{array}$ & $\begin{array}{l}\text { Probit Regresyon } \\
\text { Modeli }\end{array}$ & $2000-2001$ & $\begin{array}{l}\text { Kaldıraç kullanımı arttıkça, firmalar } \\
\text { büyüdükçe ve kar payı dağıtımı arttıkça türev } \\
\text { ürün kullanımı artmaktadır. }\end{array}$ \\
\hline $\begin{array}{c}\text { Takao ve } \\
\text { Lantara }(2010)\end{array}$ & Japonya & $\begin{array}{l}\text { Probit Regresyon } \\
\text { Modeli }\end{array}$ & 2001-2008 & $\begin{array}{l}\text { Firma büyüklüğü, stok bağımlılığı, kaldıraç } \\
\text { seviyesi arttıkça türev ürün kullanımı } \\
\text { artmaktadır. }\end{array}$ \\
\hline $\begin{array}{l}\text { Afza ve Alam } \\
\qquad(2011)\end{array}$ & Pakistan & $\begin{array}{l}\text { Tobit Regresyon } \\
\text { Analizi }\end{array}$ & 2004-2008 & $\begin{array}{l}\text { Finansal olmayan firmalarda finansal sıkıntı } \\
\text { maliyetleri ve çalışanların yönetimdeki oranı } \\
\text { arttıkça türev ürün kullanımı azalmakta, } \\
\text { varlı kazanma gücü arttıça türev ürün } \\
\text { kullanımı artmaktadır. }\end{array}$ \\
\hline $\begin{array}{l}\text { Charumathi ve } \\
\text { Kota (2012) }\end{array}$ & Hindistan & $\begin{array}{l}\text { Panel Veri } \\
\text { Analizi }\end{array}$ & 2007-2009 & $\begin{array}{l}\text { Büyük ölçekli finansal olmayan kuruluşlarda } \\
\text { işletme büyüklüğü türev ürün kullanımını } \\
\text { etkileyen en önemi değişkendir. }\end{array}$ \\
\hline $\begin{array}{l}\text { Kouser vd. } \\
\quad(2016)\end{array}$ & Pakistan & $\begin{array}{l}\text { Logit Regresyon } \\
\text { Modeli }\end{array}$ & $2005-2012$ & $\begin{array}{l}\text { Firma büyüklüğü, firma yaşı, borç ödeme } \\
\text { kabiliyeti ve büyüme arttıça türev araç } \\
\text { kullanımı artmaktadır. }\end{array}$ \\
\hline Rivas vd. (2016) & Şili & $\begin{array}{l}\text { Veri Zarflama } \\
\text { Analizi }\end{array}$ & 2001 & $\begin{array}{l}\text { Türev ürün kullanımı bankaların etkinliğini } \\
\text { arttırmaktadır. }\end{array}$ \\
\hline Khan vd. (2018) & Pakistan & Probit Model & 2004-2016 & $\begin{array}{l}\text { Ticari aktivite arttıkça, likidite düzeyi } \\
\text { yükseldikçe ve firmalar büyüdükçe türev } \\
\text { ürün kullanımı artmakta; finansal sıkıntı } \\
\text { arttıkça türev ürün kullanımı azalmaktadır. } \\
\text { Risk ve türev araç kullanımı arasındaki ilişki } \\
\text { ise türev enstrümanına göre değişmektedir. }\end{array}$ \\
\hline $\begin{array}{l}\text { Chickwira vd. } \\
\text { (2021) }\end{array}$ & Güney Afrika & $\begin{array}{l}\text { VAR Modeli, } \\
\text { Granger } \\
\text { Nedensellik }\end{array}$ & $1996-2018$ & $\begin{array}{l}\text { Kısa ve uzun dönemde ekonomik büyüme ile } \\
\text { türev ürün kullanımı arasında negatif ilişki } \\
\text { vardır, Banka borç düzeyi ve firma değeri ile } \\
\text { türev ürün kullanımı arasında çift yönlü } \\
\text { Granger nedensellik vardır. }\end{array}$ \\
\hline
\end{tabular}

Yukarıda da görüldüğü üzere uluslararası literatürde türev ürün kullanımı konusu bu alandaki Türkçe literatürde olduğu gibi çok farklı değişken setlerini içermektedir. Bu nedenle çalışmamızın uygulama kısmının daha kapsayıcı olması için hem finansal hem de makroekonomik değişkenler analize dâhil edilmiştir.

\section{Metodoloji ve Veri Seti}

$\mathrm{Bu}$ bölümde ilk olarak çalışmanın uygulama kısmında kullanılan yöntemin teorik temelleri özetlenmeye çalışılacaktır. Daha sonraki aşamada ise analizlerde kullanılan veriler hakkında bilgi verilecektir. 


\subsection{Metodoloji}

Klasik regresyon analizinde serilerin durağan oldukları varsayılırken çoğu zaman serisinin durağan olmadığı tespit edilmiş ve durağan olmayan seriler için Johansen ve Engle-Granger eşbütünleşme yöntemleri geliştirilmiştir. Fakat bu iki yöntem de sadece aynı derecede $[\mathrm{I}(0)$ veya $\mathrm{I}(1)]$ durağan olan seriler için kullanılabildiğinden farklı derecede durağan olan zaman serileri için “Gecikmesi Dağıtılmış Otoregresif Sınır Testi (ARDL)” yöntemi geliştirilmiştir (Peseran ve Shin, 1997).

ARDL yönteminde F testi ile hesaplanan istatistik değeri Peseran vd. (2001)'de açıklanan sınır değerleri (alt sınır ve üst sınır) ile karşılaştırılır. F istatistiği değeri alt sınır değerinin altında ya da üst sınır değerinin üzerinde ise eşbütünleşme vardır. Bulunan $\mathrm{F}$ istatistiği değeri alt sınır ve üst sınır değerleri arasında ise eşbütünleşme konusunda yorum yapılamaz. Eğer değişkenler arasında eşbütünleşme tespit edilmiş ise uzun dönem katsayıların tahminine geçilir (Akel ve Gazel, 2014; s. 31).

ARDL yönteminin bir sonraki aşamasında kısa dönem ilişkilerini açıklamak üzere uzun dönem denkleminin hata terimi bağımsız değişken olarak alınır ve kısa dönem ilişkilerini açıklayan model hesaplanır. Söz konusu modelde hata düzeltme teriminin katsayısının negatif ve anlamlı olması beklenir (Erdoğan ve Bozkurt, 2008; s. 30).

\subsection{Veri Seti}

Çalışmada kullanılan finansal içerikli veri setleri Türkiye'de faaliyette bulunan ve veri kaynağı kapsamındaki 32 adet bankaya ait toplulaştırılmış verilerdir. Makroekonomik veriler (kur, faiz, enflasyon) ise ülke ekonomisini temsil etmektedir. Analizlerde kullanılan zaman serisi verilerine ait kısaltmalar, tanımlamalar, gözlem aralıkları ve veri kaynakları Tablo 3'te sunulmuştur.

Tablo 3: Verilerin Tanımlanması ve Veri Kaynakları

\begin{tabular}{|c|c|c|c|}
\hline Kisaltma & Tanım & Dönem (Gözlem) & Veri Kaynağı \\
\hline LOGDER & $\begin{array}{l}\text { Türev Finansal Araçlar Toplam İşlem } \\
\text { Hacmi (Milyon TL) (Logaritmik) }\end{array}$ & 2005M1-2021M2 (194) & BDDK Web Sitesi \\
\hline LOGSIZE & $\begin{array}{l}\text { Toplam Aktifler (İşletme Büyüklüğü) } \\
\text { (Milyon TL) (Logaritmik) }\end{array}$ & 2005M1-2021M2 (194) & BDDK Web Sitesi \\
\hline LOGPRO & $\begin{array}{l}\text { Dönem Karı/Zararı (Karlılık 1) (Milyon } \\
\text { TL) (Logaritmik) }\end{array}$ & 2005M1-2021M2 (194) & BDDK Web Sitesi \\
\hline ROA & $\begin{array}{l}\text { Aktif Karlılı̆̆ (Karlılık 2) } \\
\text { ROA= (Dönem Net Karı/Zararı) / (Aktif } \\
\text { Toplamı) }\end{array}$ & 2005M1-2021M2 (194) & BDDK Web Sitesi \\
\hline ROE & $\begin{array}{l}\text { Öz Sermaye Karlılığı (Karlılık 3) } \\
\text { ROE=(Dönem Net Karı/Zararı) / (Öz } \\
\text { Sermaye) }\end{array}$ & 2005M1-2021M2 (194) & BDDK Web Sitesi \\
\hline FR & $\begin{array}{l}\text { Finansal Risk (Risk 1) } \\
\text { FR=Yabanc1 Kaynaklar/Pasif Toplamı }\end{array}$ & 2005M1-2021M2 (194) & BDDK Web Sitesi \\
\hline CR & $\begin{array}{l}\text { Kredi Riski (Risk 2) } \\
\text { KR=Takipteki Alacaklar/Krediler }\end{array}$ & 2005M1-2021M2 (194) & BDDK Web Sitesi \\
\hline ERR & $\begin{array}{l}\text { Döviz Kuru Riski (Risk } 3 \text { ) } \\
\text { ERR= (Yabancı Para Toplam Aktifler / } \\
\text { Yabancı Para Toplam Pasifler) }\end{array}$ & 2005M1-2021M2 (194) & BDDK Web Sitesi \\
\hline INF & Enflasyon (2003=100 Endeks) & 2005M1-2021M2 (194) & TCMB EVDS \\
\hline IR & $\begin{array}{l}\text { Faiz Oranı (Bankaların TL Mevduatlarına } \\
\text { Uygulanan) }\end{array}$ & 2005M1-2021M2 (194) & TCMB EVDS \\
\hline ER & Döviz Kuru (USD/TL) & 2005M1-2021M2 (194) & TCMB EVDS \\
\hline
\end{tabular}

Veri setleri tanımlandıktan sonra kullanılan finansal ve makroekonomik değişkenlere ait tanımlayıcı istatistikler Tablo 4'te verilmiştir. Bu gösterimde değişkenlerin ham verileri dikkate alınarak analize tabi tutulmuştur. 
Tablo 4: Değişkenlerin Tanımlayıcı İstatistikleri

\begin{tabular}{|c|c|c|c|c|c|c|c|c|c|c|c|}
\hline & DER & SIZE & PRO & ROA & ROE & FR & $\mathbf{C R}$ & ERR & INF & IR & ER \\
\hline Ortalama & 1.209 .853 & 1.753 .902 & 14.000 & 0,0095 & 0,0846 & 0,8872 & 0,0392 & 1,0006 & 243,41 & 11,66 & 2,72 \\
\hline Medyan & 674.368 & 1.258 .783 & 11.196 & 0,0090 & 0,0834 & 0,8891 & 0,0351 & 1,0003 & 217,06 & 9,77 & 1,81 \\
\hline Maximum & 3.800 .675 & 5.388 .037 & 48.688 & 0,0250 & 0,2086 & 0,9131 & 0,0660 & 1,0126 & 517,96 & 22,85 & 7,99 \\
\hline Minimum & 41.768 & 290.500 & 750 & 0,0006 & 0,0062 & 0,8539 & 0,0277 & 0,9838 & 114,49 & 5,26 & 1,16 \\
\hline $\begin{array}{c}\text { Std, } \\
\text { Sapma }\end{array}$ & 1.144 .493 & 1.330 .096 & 11.195 & 0,0057 & 0,0489 & 0,0094 & 0,0101 & 0,0041 & 105,48 & 4,44 & 1,77 \\
\hline Skewness & 0,79 & 0,99 & 1,19 & 0,55 & 0,39 & $-0,65$ & 0,81 & $-0,01$ & 0,88 & 0,63 & 1,37 \\
\hline Kurtosis & 2,26 & 3,08 & 3,86 & 2,73 & 2,48 & 3,87 & 2,46 & 3,97 & 2,81 & 2,15 & 3,75 \\
\hline $\begin{array}{c}\text { Jarque- } \\
\text { Bera } \\
\end{array}$ & 24,72 & 32,27 & 52,22 & 10,46 & 7,19 & 19,94 & 23,78 & 7,76 & 25,55 & 18,67 & 65,79 \\
\hline Olasılık & 0,000 & 0,000 & 0,000 & 0,005 & 0,027 & 0,000 & 0,000 & 0,020 & 0,000 & 0,000 & 0,000 \\
\hline Gözlem & 194 & 194 & 194 & 194 & 194 & 194 & 194 & 194 & 194 & 194 & 194 \\
\hline
\end{tabular}

Tablo 4 incelendiğinde değişkenlerin normal dağılıma sahip olduğu görülmektedir. Diğer taraftan standart sapmanın beklenen değere (ortalamaya) oranlamasıyla bulunan değişim (varyasyon) katsayısı açısından ise türev araç kullanım hacmi (DER) (\% 95), kar (PRO) (\% 80) ve büyüklük (SIZE) (\% 76) değişkenleri yıllar itibariyle en yüksek değişkenliğe sahiptir.

\section{Analiz ve Bulgular}

Çalışmada gerçekleştirilen analiz kapsamında ilk olarak değişkenlerin korelasyon analizi yapılmıştır. Bu doğrultuda Tablo 5'te değişkenler arasındaki ilişkinin yönünü ve gücünü açıklayan korelasyon bulguları sunulmuştur.

Tablo 5: Korelasyon Analizi*,**

\begin{tabular}{|l|c|c|c|c|c|c|c|c|c|c|c|}
\hline & DER & SIZE & PRO & ROA & ROE & FR & CR & ERR & INF & IR & ER \\
\hline DER & 1 & - & - & - & - & - & - & - & - & - & - \\
\hline SIZE &, $986^{* *}$ & 1 & - & - & - & - & - & - & - & - & - \\
\hline PRO &, $652^{* *}$ &, $652^{* *}$ & 1 & - & - & - & - & - & - & - & - \\
\hline ROA &,$- 375^{* *}$ &,$- 368^{* *}$ &, $284^{* *}$ & 1 & - & - & - & - & - & - & - \\
\hline ROE &,$- 308^{* *}$ &,$- 302^{* *}$ &, $356^{* *}$ &, $990^{* *}$ & 1 & - & - & - & - & - & - \\
\hline FR &, $663^{* *}$ &, $662^{* *}$ &, $451^{* *}$ &,$- 214^{* *}$ &,- 093 & 1 & - & - & - & - & - \\
\hline CR &, 007 &, 033 &,- 027 &, 082 &, 030 &,$- 378^{* *}$ & 1 & - & - & - & - \\
\hline ERR &, $219^{* *}$ &, $220^{* *}$ &, $168^{*}$ &,- 005 &,- 016 &,- 005 &,- 073 & 1 & - & - & - \\
\hline INF &, $981^{* *}$ &, $994^{* *}$ &, $642^{* *}$ &,$- 371^{* *}$ &,$- 309^{* *}$ &, $642^{* *}$ &, 036 &, $271^{* *}$ & 1 & - & - \\
\hline IR &, 044 &,- 008 &,- 029 &, 087 &, 113 &, 081 &, $297^{* *}$ &,- 017 &, 019 & 1 & - \\
\hline ER &, $964^{* *}$ &, $980^{* *}$ &, $634^{* *}$ &,$- 340^{* *}$ &,$- 275^{* *}$ &, $634^{* *}$ &, $170^{*}$ &, $201^{* *}$ &, $973^{* *}$ &, 0126 & 1 \\
\hline
\end{tabular}

*\% 5 önem seviyesinde anlamlı, **\% 1 önem seviyesinde anlamlı

Tablo 5'e bakıldığında türev araç kullanım hacmi (DER)'nin kredi riski (CR) ve faiz oranı (IR) hariç diğer tüm değişkenlerle anlamlı bir ilişkiye sahip olduğu görülmektedir. Bununla beraber, türev araç kullanım hacmi (DER) 
ile sırasıyla büyüklük (SIZE) (0,986), enflasyon (INF) (0,981), döviz kuru (ER) $(0,964)$, finansal risk (FR) $(0,663)$, kar (PRO) $(0,652)$ ve döviz kuru riski (ERR) $(0,219)$ değişkenleri arasında pozitif korelasyon vardır. Yine türev araç kullanım hacmi (DER) ile sırasıyla aktif karlılığı (ROA) $(-0,375)$ ve öz sermaye karlılı̆̆ı $(\mathrm{ROE})(-0,308)$ arasında negatif korelasyon vardır.

Çalışmanın bu kısmında, literatür 1şığında ARDL metodu, En Küçük Kareler yöntemini esas alması sebebiyle serilerin durağanlık sınamaları yapılmıştır. Birim kök diğer bir deyişle durağanlık test sonuçları Tablo 6'da sunulmuştur.

Tablo 6: Birim Kök (Durağanlık) Analizi*,**

\begin{tabular}{|l|c|c|c|c|c|c|c|}
\hline \multirow{2}{*}{$\begin{array}{c}\text { Model Özelliği: } \\
\begin{array}{c}\text { Trendli ve Sabit } \\
\text { Terimli }\end{array}\end{array}$} & \multicolumn{2}{|c|}{ ADF } & \multicolumn{2}{c|}{ PP } & \multicolumn{2}{c|}{ KPSS } & \multirow{2}{*}{ Sonuç } \\
\cline { 2 - 8 } LogDER & $-2,17$ & $-14,93$ & $-1,84$ & $-17,44$ & 0,38 & 0,05 & I (1) \\
\hline LogSIZE & $-4,33$ & $-14,06$ & $-4,38$ & $-14,29$ & 0,14 & 0,05 & I (0) \\
\hline LOgPRO & $-2,92$ & $-4,52$ & $-7,13$ & $-46,35$ & 0,05 & 0,08 & I (0) \\
\hline ROA & $-3,69$ & $-3,76$ & $-5,72$ & $-19,25$ & 0,08 & 0,05 & I (0) \\
\hline ROE & $-3,55$ & $-3,87$ & $-5,75$ & $-20,21$ & 0,08 & 0,05 & I (0) \\
\hline FR & $-4,54$ & $-11,26$ & $-4,58$ & $-13,31$ & 0,07 & 0,06 & I (0) \\
\hline CR & $-3,11$ & $-4,23$ & $-2,53$ & $-7,57$ & 0,24 & 0,04 & I (1) \\
\hline ERR & $-5,54$ & $-17,56$ & $-5,64$ & $-18,12$ & 0,13 & 0,04 & I (0) \\
\hline INF & 3,25 & $-7,31$ & 3,41 & $-9,73$ & 0,38 & 0,29 & I (1) \\
\hline IR & $-2,16$ & $-7,25$ & $-2,07$ & $-6,10$ & 0,31 & 0,03 & I (1) \\
\hline ER & $-0,58$ & $-11,16$ & $-0,76$ & $-7,71$ & 0,39 & 0,04 & I (1) \\
\hline
\end{tabular}

*Kritik Değerler: ADF ve PP (McKinnon (1996)): Trendli ve Sabit Terimli \%1 (-4,00), \%5 (-3,43), \%10 (-3,14), KPSS (Kwiatkowski-PhilipsSchmidt-Shin (1992, Table 1)): Trendli ve Sabit Terimli: \%1 $(0,21), \% 5(0,14), \% 10(0,11) . * *$ Serilerin grafiksel görünümüne bakılarak tüm seriler için en uygun modelin "Trendli ve Sabit Terimli" model olduğu görülmüștür. Analizde maksimum gecikme uzunluğu 14 olarak belirlenmiş ve model seçim kriteri olarak Schwarz Bilgi Kriteri (SC) kullanılmıştır.

Tablo 6'dan türev araç kullanım hacmi (LogDER), kredi riski (CR), enflasyon (INF), faiz oranı (IR) ve döviz kuru (ER) serilerinin birinci farklarında durağan I (1) olduğu ve büyüklük (LogSIZE), kar (LogPRO), aktif karlılığ1 (ROA), öz sermaye karlılığı (ROE), finansal risk (FR) ve döviz kuru riski (ERR) serilerinin ise düzeyde durağan I (0) olduğu görülmektedir.

Çalışmada Hassan ve Khasawneh (2009), Anbar ve Alper (2011), Khan vd. (2018) ve Kuzu ve Çelik (2019)'e göre kurulan doğrusal ekonometrik model şöyledir:

$\log D E R=a+\beta_{1} \operatorname{LogSIZE}+\beta_{2} \log P R O+\beta_{3} R O A+\beta_{4} R O E+\beta_{5} F R+\beta_{6} C R+\beta_{7} E R R+\beta_{8} I N F+\beta_{9} I R+\beta_{10} E R+\varepsilon$ Durağanlık analizi ve modelin açıklanması sonrasında, bankaların kullandığı toplam türev araç kullanımını etkileyen finansal ve makroekonomik değişkenlerin belirlenmesi amacıyla, değişkenler arasındaki temel ilişkileri açıklamaya yardımcı olabilecek Otoregressif Dağıtılmış Gecikmeli (ARDL) modeli tahmini yapılmıştır.

ARDL modeli tahmin sonuçları Tablo 7'de özetlenmiştir. 
Finans Ekonomi ve Sosyal Araştırmalar Dergisi, Cilt.6 Sayı.3, Eylül 2021

Tablo 7: ARDL $(1,0,0,0,1,1,0,3,1,1,0)$ Eşitliği Tahmin Sonuçları

\begin{tabular}{|c|c|c|c|c|}
\hline \multirow{2}{*}{$\begin{array}{l}\text { Bağımlı Değişken: LogDER } \\
\text { Bağımsız Değişkenler }\end{array}$} & \multicolumn{2}{|c|}{ Yöntem: ARDL } & \multicolumn{2}{|c|}{$\begin{array}{c}\text { Örneklem: } \\
\text { 2005M1-2021M2 }\end{array}$} \\
\hline & Katsay 1 & $\underline{\text { Standart Hata }}$ & $\underline{t \text { istatistiği }}$ & Olasılık \\
\hline $\operatorname{LogDER}(-1)$ & $0,767092 * * *$ & 0,053363 & 14,37507 & 0,0000 \\
\hline LogSIZE & $0,435750 * * *$ & 0,107424 & 4,056360 & 0,0001 \\
\hline LogPRO & 0,022168 & 0,017883 & 1,239644 & 0,2168 \\
\hline $\mathrm{ROA}$ & 2,624250 & 10,25763 & 0,255834 & 0,7984 \\
\hline ROE & $-1,135166$ & 1,344688 & $-0,844185$ & 0,3997 \\
\hline $\operatorname{ROE}(-1)$ & $0,332287 * *$ & 0,136333 & 2,437322 & 0,0158 \\
\hline FR & $4,663075^{* * *}$ & 1,504772 & 3,098859 & 0,0023 \\
\hline FR(-1) & $-5,027780 * * *$ & 1,096866 & $-4,583767$ & 0,0000 \\
\hline $\mathrm{CR}$ & $-0,902791$ & 0,722220 & $-1,250022$ & 0,2130 \\
\hline ERR & $-1,452158$ & 1,400328 & $-1,037012$ & 0,3012 \\
\hline $\operatorname{ERR}(-1)$ & 1,376847 & 1,588073 & 0,866992 & 0,3872 \\
\hline $\operatorname{ERR}(-2)$ & $-2,254894$ & 1,536859 & $-1,467209$ & 0,1441 \\
\hline $\operatorname{ERR}(-3)$ & $3,419132 * *$ & 1,312381 & 2,605289 & 0,0100 \\
\hline INF & $0,003406^{*}$ & 0,001909 & 1,784133 & 0,0762 \\
\hline $\operatorname{INF}(-1)$ & $-0,003664 * *$ & 0,001735 & $-2,112401$ & 0,0361 \\
\hline IR & $-0,007280$ & 0,006380 & $-1,140913$ & 0,2555 \\
\hline $\operatorname{IR}(-1)$ & 0,008908 & 0,006010 & 1,482169 & 0,1401 \\
\hline ER & $-0,034533$ & 0,026037 & $-1,326292$ & 0,1865 \\
\hline $\mathrm{C}$ & $-3,766628$ & 2,282445 & $-1,650260$ & 0,1007 \\
\hline $\mathrm{R}^{2}$ & 0,9986 & Akaike Bilgi K & & $-3,1352$ \\
\hline Düzeltilmiş $\mathrm{R}^{2}$ & 0,9985 & Schwarz Kriter & & $-2,8116$ \\
\hline Durbin-Watson İst. & 2,1358 & Hannan-Quin $\mathrm{K}$ & & $-3,0041$ \\
\hline F-İstatistiği & 7278,4 & Olasılık (F İsta & iği) & 0,0000 \\
\hline
\end{tabular}

ARDL eşitliğine göre türev araç kullanım miktarı bir önceki dönemden (LogDER(-1)) pozitif etkilenmektedir. Bununla birlikte türev araç kullanım miktarı (LogDER) büyüklük (Log SIZE), öz sermaye karlılığının bir dönem gecikmeli değeri (ROE(-1)), finansal risk (FR), döviz kuru riskinin üç dönem gecikmeli değeri (ERR(-3) ve enflasyon (INF) değişkenleri ile pozitif ve anlamlı bir ilişkiye sahipken; finansal riskin bir dönem gecikmeli değeri (FR(-1)) ve enflasyonun bir dönem gecikmeli değeri (INF(-1)) ile negatif ve anlamlı bir ilişkiye sahiptir. Bu sonuçlara göre büyüklük, bir dönem gecikmeli öz sermaye karlılığı, finansal risk, üç dönem gecikmeli döviz kuru riski ve enflasyon arttıkça türev araç kullanımı artmaktadır. Benzer şekilde bir dönem gecikmeli finansal risk ve bir dönem gecikmeli enflasyon oranı arttıkça türev ürün kullanım miktarı azalmaktadır.

ARDL denkleminden yola çıkılarak hesaplanan ve bir bütün olarak bağımsız değişkenler ile bağımlı değişken arasından uzun dönemli bir eşbütünleşme ilişkisinin olup olmadığını belirlemek için yapılan sınır testi sonucu Tablo 8'de verilmiştir.

Tablo 8: ARDL Sınır Testi Sonuçları

\begin{tabular}{|c|c|c|c|c|}
\hline \multirow{2}{*}{$\begin{array}{c}\begin{array}{c}\text { Bağımsız Değişken } \\
\text { Sayısı }\end{array} \\
10 \\
\end{array}$} & \multirow{2}{*}{$\begin{array}{c}\mathbf{F} \\
\text { İstatistiği } \\
483\end{array}$} & \multicolumn{2}{|c|}{ Kritik Değerler (\% 5) } & \multirow{2}{*}{$\begin{array}{c}\text { Sonuç } \\
\text { Eşbütünleşme var }\end{array}$} \\
\hline & & $\frac{\text { Alt Sinır I(0) }}{1,98}$ & $\frac{\text { Üst Sınır I(1) }}{3,04}$ & \\
\hline
\end{tabular}

Tablo 8'den da görüldüğü üzere hesaplanan F İstatistiği (F=4,83) değeri \% 5 önem seviyesindeki kritik değerlerden oluşan alt sınır ve üst sınır değerlerinin üzerinde olduğu için değişkenler arasında en az bir eşbütünleşme vektörü olduğu bulgusuna ulaşılmıştır. Bu sonuca göre modelimizdeki değgişkenler arasında uzun dönemli beraber hareket etme ilişkisi olduğu söylenebilir.

ARDL sınır testinin ardından Tablo 9'da değişkenlerin uzun dönem tahmin sonuçları verilmiştir. 
Finans Ekonomi ve Sosyal Araştırmalar Dergisi, Cilt.6 Sayı.3, Eylül 2021

Tablo 9: ARDL Modeli Uzun Dönem Tahminleri

\begin{tabular}{|c|c|c|c|c|}
\hline \multirow{2}{*}{$\begin{array}{l}\text { Bağımlı Değişken: LogDER } \\
\text { Bağımsız Değişkenler }\end{array}$} & \multicolumn{2}{|c|}{$\begin{array}{l}\text { Yöntem: ARDL Uzun Dönem } \\
\text { Katsavilar }\end{array}$} & \multicolumn{2}{|c|}{$\begin{array}{c}\text { Örneklem: } \\
\text { 2005M1-2021M2 }\end{array}$} \\
\hline & $\underline{\text { Katsay } 1}$ & $\underline{\text { Standart Hata }}$ & t istatistiğ & Olasılık \\
\hline $\mathrm{C}$ & $-3,766628$ & 2,282445 & $-1,650260$ & 0,1007 \\
\hline $\operatorname{LogDER}(-1)$ & $-0,232908 * * *$ & 0,053363 & $-4,364623$ & 0,0000 \\
\hline LogSIZE & $0,435750 * * *$ & 0,107424 & 4,056360 & 0,0001 \\
\hline LogPRO & 0,022168 & 0,017883 & 1,239644 & 0,2168 \\
\hline ROA & 2,624250 & 10,25763 & 0,255834 & 0,7984 \\
\hline $\operatorname{ROE}(-1)$ & $-0,802878$ & 1,291825 & $-0,621507$ & 0,5351 \\
\hline $\mathrm{FR}(-1)$ & $-0,364705$ & 1,274454 & $-0,286166$ & 0,7751 \\
\hline $\mathrm{CR}^{* *}$ & $-0,902791$ & 0,722220 & $-1,250022$ & 0,2130 \\
\hline $\operatorname{ERR}(-1)$ & 1,088927 & 1,421384 & 0,766104 & 0,4447 \\
\hline $\operatorname{INF}(-1)$ & $-0,000258$ & 0,000515 & $-0,500728$ & 0,6172 \\
\hline $\operatorname{IR}(-1)$ & 0,001628 & 0,001382 & 1,177907 & 0,2405 \\
\hline $\mathrm{ER}^{* *}$ & $-0,034533$ & 0,026037 & $-1,326292$ & 0,1865 \\
\hline $\mathrm{D}(\mathrm{ROE})$ & $-1,135166$ & 1,344688 & $-0,844185$ & 0,3997 \\
\hline $\mathrm{D}(\mathrm{FR})$ & $4,663075 * * *$ & 1,504772 & 3,098859 & 0,0023 \\
\hline $\mathrm{D}(\mathrm{ERR})$ & $-1,452158$ & 1,400328 & $-1,037012$ & 0,3012 \\
\hline $\mathrm{D}(\operatorname{ERR}(-1))$ & $-1,164238$ & 1,498511 & $-0,776930$ & 0,4383 \\
\hline $\mathrm{D}(\operatorname{ERR}(-2))$ & $-3,419132 * *$ & 1,312381 & $-2,605289$ & 0,0100 \\
\hline D(INF) & $0,003406^{*}$ & 0,001909 & 1,784133 & 0,0762 \\
\hline $\mathrm{D}(\mathrm{IR})$ & $-0,007280$ & 0,006380 & $-1,140913$ & 0,2555 \\
\hline
\end{tabular}

***,***: Sirasıyla $\% 10, \% 5$ ve $\% 1$ önem seviyesinde anlamlı

Uzun dönem tahminlerine bakıldığında türev araç kullanımının bir dönem gecikmeli değerinin (LOGDER(-1)), büyüklük değişkeninin (LOGSIZE), finansal risk değişkeninin farkınının (D(FR)) \% 1 önem seviyesinde; döviz kuru riski farkının iki dönem gecikmeli değerinini $(\mathrm{D}(\operatorname{ERR}(-2)) \% 5$ önem seviyesinde ve enflasyon değişkeni farkının (D(INF)) \% 10 önem seviyesinde anlamlı olduğu görülmektedir.

ARDL modelinde modelin sağlamlığını test etmek için "Cusum" ve "Cusum of Squares" grafiğine bakılabilir. Parametre istikrarını gösteren söz konusu grafikler aşağıda verilmiştir.

Şekil 1: "Cusum” ve “Cusum of Squares” Testleri
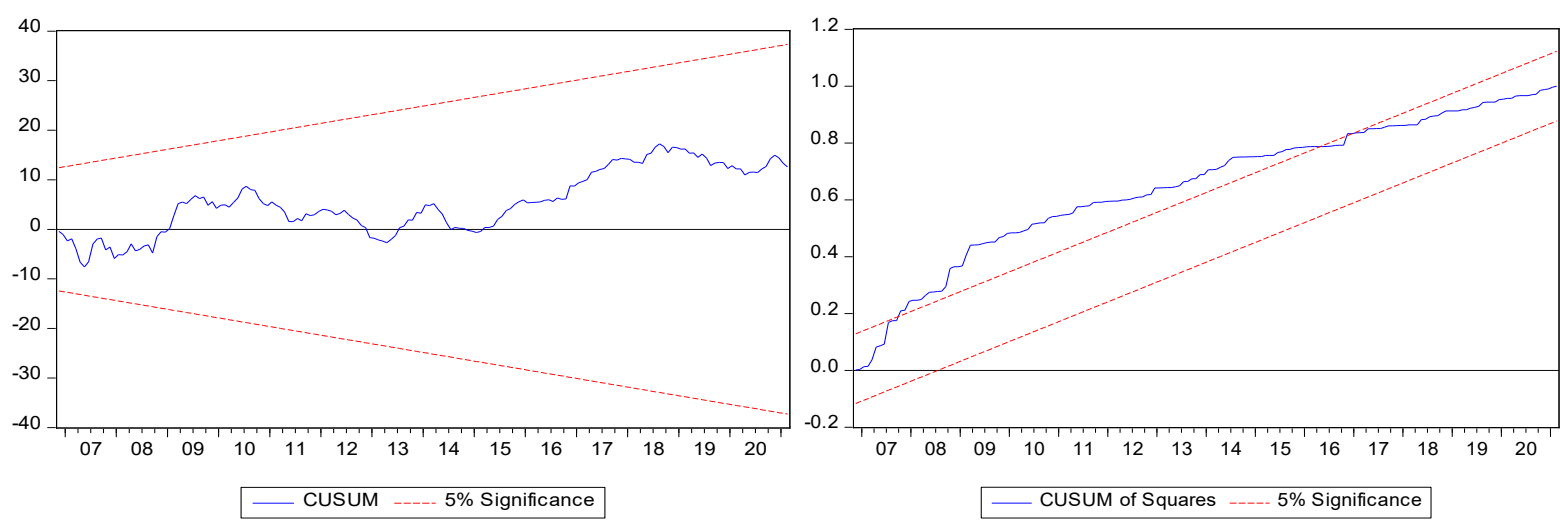

Şekil 1'den de görüldüğü üzere “Cusum” testine göre ulaşılan değerler kırmızı sınır çizgileri arasında olduğu için parametre istikrarı sağlanmıştır. Fakat "Cusum of Squares" testinde parametre istikrarının sağlanmadığı diğer bir ifadeyle modelde yapısal kırılma olabileceği gözlemlenmektedir. Bu sonuçtan hareketle gelecek çalışmalarda benzer değişkenlerle benzer dönem aralığında yapısal kırılmaları dikkate alan yöntemlerin kullanılarak analizlerin yapılması önerilmektedir.

ARDL yönteminin son aşaması olarak kısa dönemli ilişkileri açıklamak üzere hata düzeltme modelinin çalışıp çalışmadığı incelenecektir. Hata düzeltme modelinde uzun dönem tahmin modelindeki hata terimlerinin bir 
Finans Ekonomi ve Sosyal Araştırmalar Dergisi, Cilt.6 Sayı.3, Eylül 2021

gecikmeli değeri (ECM(-1)) bağımsız değişkenler içerisine alınarak kısa dönem için model kurulmaktadır. Söz konusu modelin parametreleri Tablo 10'da verilmiştir.

Tablo 10: Hata Düzeltme Modeli

\begin{tabular}{|l|c|c|c|c|}
\hline Bağımlı Değişken: D(LogDER) \\
\hline Bağımsız Değişkenler & $\underline{\text { Katsay1 }}$ & Standart Hata & t istatistiği & Olasılık \\
\hline LogSIZE & 0,013522 & 0,017256 & 0,783632 & 0,4343 \\
\hline LogPRO & $-0,022991^{*}$ & 0,013655 & $-1,683679$ & 0,0940 \\
\hline ROA & $-15,32508$ & 10,60143 & $-1,445568$ & 0,1501 \\
\hline ROE & 1,834648 & 1,288844 & 1,423483 & 0,1563 \\
\hline FR & $-1,790540$ & 1,210519 & $-1,479151$ & 0,1409 \\
\hline D(CR) & $-8,466259^{* *}$ & 3,259302 & $-2,597568$ & 0,0102 \\
\hline ERR & $-1,091682$ & 1,137579 & $-0,959654$ & 0,3385 \\
\hline D(INF) & 0,000735 & 0,001794 & 0,409651 & 0,6826 \\
\hline D(IR) & $-0,015410^{* * *}$ & 0,005577 & $-2,762855$ & 0,0063 \\
\hline D(ER) & $0,093625^{* * *}$ & 0,033247 & 2,816003 & 0,0054 \\
\hline ECM (-1) & $\mathbf{- 0 , 2 7 0 0 0 3 * * *}$ & 0,090835 & $-2,972465$ & 0,0034 \\
\hline c & $2,711817^{*}$ & 1,612833 & 1,681400 & 0,0944 \\
\hline$R^{2}$ & 0,2837 & Akaike Bilgi Kriteri & $-2,9919$ \\
\hline Düzeltilmiş R ${ }^{2}$ & 0,2395 & Schwarz Kriteri & $-2,7868$ \\
\hline Durbin-Watson İst. & 1,8966 & Hannan-Quin Kriteri & $-2,9088$ \\
\hline F-İstatistiği & 6,41129 & Olasilik (F İstatistiği) & 0,0000 \\
\hline
\end{tabular}

*,****: Strasiyla \% 10, \% 5 ve \%1 önem seviyesinde anlamlı. Jarque-Bera (Olasılık): 17,59294 (0,000151). Breusch-Godfrey LM Otokorelasyon Testi (2): 1,067215 (0,3462). Heteroskedasticity (Değişen Varyans): 1,841917 (0,0016).

Kısa dönem analizi içeren hata düzeltme modelinde uzun dönem denkleminden elde edilen hata teriminin bir dönem gecikmeli değeri(ECM(-1)) ’nin katsayısı anlamlı $(p=0,0034)$ ve negatiftir $(-0,270003)$. Dolayısıyla hata düzeltme mekanizması çalışmaktadır ve uzun dönemli eşbütünleşme ilişkisi kısa dönemde de söz konusudur.

\section{Sonuç}

Türev ürünler özellikle piyasalarda yüksek dalgalanma olduğu dönemlerde başvurulabilecek önemli risk yönetim araçlarındandır. Türkiye'de finansal sistemin en önde gelen bileşenlerinden olan bankalar fon ya da varlık yönetimindeki risk ya da belirsizlikleri en aza indirmek için özellikle 2000'li yıllardan sonra portföylerinde türev araç bulundurmaya yönelmişlerdir. Söz konusu dönem içerisinde türev ürün kullanımının hem sözleşme sayısı hem de işlem hacmi açısından hızla artması bankaların türev ürün kullanım miktarını belirleyen değişkenlerin tespit edilmesini gerekli kılmıştır. Nitekim bu çalışmada Türkiye'de bankaların türev ürün kullanım hacmini etkileyen finansal ve makroekonomik değişkenler belirlenmeye çalışılmıştır. Literatürde bu alanda çok farklı sayıda finansal ya da ekonomik değişken setleriyle ve yine çok farklı sayısal yöntemlerle analizler yapıldığı görülmektedir. Bu doğrultuda çalışmada gerek seçilen değişken kombinasyonu gerekse kullanılan yöntemin daha önce bu alanda kullanılmamış olması açısından literatüre katkıda bulunabileceği düşünülmektedir.

Çalışmada yapılan korelasyon ve ARDL sınır testi analizlerinin ortak bulgusu bankaların aktif büyüklükleri arttıkça türev araç kullanım hacminin de artıyor olmasıdır. Bu sonuç Hundman (1999), Shiu (2007), Takao ve Lantara (2010), Dündar (2011), Charumathi ve Kota (2012), Doğan (2013), Durmuş (2016), Khan vd. (2018), Çankaya ve Güçver (2019) ve Durmuş ve Coşkun (2019)'un bulgularıyla aynı yönlü; Carter ve Sinkey (1998)'in bulguları ile çelişkilidir. Çalışmada yapılan analiz sonuçları genel olarak değerlendirildiğinde, Türkiye’de bankaların türev ürün kullanım hacmi üzerinde bankalara veya ekonomiye dair risklerdeki artışın da önemli rol aldığı söylenebilir. Nitekim finansal risk ve döviz kuru risklerinin bağımlı değişken olarak belirlenen türev araç kullanım miktarı üzerinde düzey değerlerinde ya da gecikmeli olarak etkilerinin olduğu tespit edilmiştir. Elde edilen bu bulgu risk arttıkça riski yönetmek için kullanılan riskten korunma araçlarının da artacağını açıklayan finans teorisiyle de uyumludur. Bu sonuç Carter ve Sinkey (1998), Shiu (2007), Şimşek (2015), Durmuş (2016) ve Durmuş ve Coşkun (2019)'un bulgularıyla aynı yönde; Hassan ve Khasawneh (2009) ve Şirvan ve Alp (2017)'in bulgularıyla zıt yöndedir. Diğer taraftan yapılan analizlerde türev ürün kullanım hacmi ile öz sermaye karlılığı arasında negatif yönlü bir ilişki olduğu görülmüştür. Söz konusu ters yönlü ilişkinin yatırılan sermayenin alternatif maliyetinden kaynaklanabileceği öngörülmektedir. Literatüre bakıldığında ise bu bulgu Yalçın (2015) ve Akkaynak ve Yıldırım (2019)'ın bulguları ile aynı doğrultuda; Anbar ve Alper (2011), Tanrı̈öen ve Yenice (2014) ve Akkaya ve Torun (2020)'un bulgularıyla çelişkilidir. Diğer taraftan çalışmada uzun dönem 
tahminlerinden sonra kısa dönemli ilişkileri açıklamak üzere hata düzeltme modeli kurulmuş ve söz konusu modelin çalıştığı gözlemlenmiştir. Buna göre uzun dönemli ilişkiler kısa dönemde de geçerlidir.

Literatürde türev piyasalar çok farklı boyutlarıyla ele alınmıştır. Yapılan çalışmalarda kurumsallaşma düzeyindeki artışın, türev araç kullanımını arttırdığına dair kanıtlar elde edilmiştir (Doğan, 2013; Kouser vd., 2016; Çankaya ve Güçver, 2019; Güven, 2019). Diğer bir ifadeyle, bankalar daha fazla kurumsallaştıkça ya da profesyonelleştikçe türev araçlara daha sık başvurmaları kuvvetle muhtemeldir. Diğer taraftan türev piyasalar üzerine çalışma yapmak isteyen araştırmacıların konuyu daha da detaylandırarak incelemeleri önerilir. Nitekim bankaların ele alındığı bu çalışmanın devamı olarak finansal olmayan kuruluşlarda türev araç kullanımı genel ekonomi ölçeğinde ya da sektörel olarak analiz edilebilir.

Sonuç olarak, riski yönetmek geleceğin ölçülebilir belirsizliklerini yönetmektir. Bir risk yönetim aracı olarak türev araçların belirsizliğin en üst düzeyde olduğu günümüzde ve büyük olasılıkla yüksek düzeyde belirsizliğin olacağ gelecekte daha da önem kazanacağı öngörülmektedir.

\section{Kaynakça}

ADKINS, L. C., CARTER, D. A. ve SIMPSON, W. G. (2007). Managerial Incentives and the Use of ForeignExchange Derivatives by Banks. The Journal of Financial Research, 30(3), 399-413.

AFZA, T. ve ALAM, A. (2011). Determinants of Extent of Financial Derivative Usage. African Journal of Business Management, 5(20), 8331-8336.

AHMED, A. S., BEATTY, A. ve TAKEDA, C. (1997). Evidence on Interest Rate Risk Management and Derivatives Usage by Commercial Banks. SSRN Electronic Journal, 1-37.

AKARSU, Y. ve ALACAHAN, D. (2020). Türkiye'de Faaliyet Gösteren Bankaların Türev Ürün Kullanımını Etkileyen Faktörler: Doğrusal Model Uygulaması. Kesit Akademi Dergisi, 6(25), 246-258.

AKEL, V. ve GAZEL, S. (2014). Döviz Kurları ile BIST Sanayi Endeksi Arasındaki Eşbütünleşme İlişkisi: Bir ARDL Sınır Testi Yaklaşımı. Erciyes Üniversitesi İktisadi ve İdari Bilimler Fakültesi Dergisi, 44, 23-41.

AKKAYA, M. ve TORUN, S. (2020). Türk Bankacılık Sektöründe Türev Ürünlerin Kullanımı ve Etkileri. Bankacılar Dergisi, 115, 38-49.

AKKAYNAK, B. ve YILDIRIM, S. (2019). Türev Ürünlerin Kullanım Amaçları: BIST'de Bir Uygulama. Erzincan Binali Yıldırım Üniversitesi Iktisadi ve İdari Bilimler Fakültesi Dergisi, 1(2), 23-33.

ANBAR, A.ve ALPER, D. (2011). Bankaların Türev Ürün Kullanım Yoğunluğunu Etkileyen Faktörlerin Belirlenmesi. Muhasebe ve Finansman Dergisi, 4, 77-94.

ASHRAF, D., ALTUNBAŞ, Y. ve GODDARD, J. (2007). Who Transfers Credit Risk? Determinants of the Use of Credit Derivatives by Large US Banks. The European Journal of Finance, 13(5), 483-500.

BARTRAM, S. M., BROWN, G. W. ve FEHLE, F. R. (2009). International Evidence on Financial Derivatives Usage. Financial Management, 2, 185-206.

BAYRAKDAROĞLU, A., SARI, B. ve HEYBELİ, B. (2013). İşletmelerin Finansal Risk Yönetiminde Türev Ürün Kullanımlarına İlişkin Bir Saha Araştırması: Denizli İli Örneği. Muhasebe ve Finansman Dergisi, 1, 57-72.

BDDK (2021). Bankacılı Düzenleme ve Denetleme Kurumu Veri Bankası. https://www.bddk.org.tr/BultenAylik/tr/Home/Gelismis, 23.05.2021.

BOZTOSUN, D., AKSOYLU, S., ALTINIŞIK, F., BARAZ, E. H. ve AKSOY, B. (2016). Dış Ticaret Yapan Firmaların Finansal Risk Yönetiminde Türev Ürünleri Kullanım Düzeylerinin İncelenmesi: Kayseri İli Örneği. Cumhuriyet Üniversitesi İktisadi ve İdari Bilimler Dergisi, 17(1), 153-168.

CARTER, D. A. ve SINKEY, J. E. (1998). The Use of Interest Rate Derivatives by End-Users: The Case of Large Community Banks. Journal of Financial Services Research, 14(1), 17-34.

CEYLAN, A. ve KORKMAZ, T. (2018). İsletmelerde Finansal Yönetim. Bursa: Ekin Kitabevi Yayınları.

CHAMBERS, N. (2007). Türev Piyasalar (2. Baskı). İstanbul: Beta Basım Yayın.

CHARUMATHI, B. ve KOTA, H. B. (2012). On the Determinants of Derivative Usage by Large Indian NonFinancial Firms. Global Business Review, 13(2), 251-267. 
CHIKWIRA, C., RAWJEEE, V. P. ve BALKARAN, R. (2021). Is there a Causality between Economic Growth Variables and Derivatives Usage?. Acta Universitatis Danubius.Economica, 17(1), 108-123.

ÇAKIR, K. Y. (2008). Tezgahüstü Türev Araçların Karşı Taraf Kredi Riskinin Ölçülmesi ve Yönetilmesi (Yeterlik Etüdü). Ankara: Sermaye Piyasası Kurulu Aracılık Faaliyetleri Dairesi.

ÇANKAYA, S. ve GÜÇVER, C. (2019). Borsa İstanbul İmalat Sanayi Endeksine Kayıtlı Firmaların Finansal Risk Yönetimlerinde Türev Ürün Kullanımının Belirleyicileri. Bankacılık Denetleme ve Düzenleme Kurulu Bankacilık ve Finansal Piyasalar, 13(2), 185-213.

ÇONKAR, K. ve ATA, H. A. (2002). Riskten Korunma Aracı Olarak Türev Ürünlerin Gelişmiş Ülkeler ve Türkiye'de Kullanımı. Afyon Kocatepe Üniversitesi İktisadi ve İdari Bilimler Fakültesi Dergisi, 4(2), 117.

DEMİR, S. (2009). Döviz Riskinden Korunma Yöntemleri ve Kullanılma Nedenleri: İMKB Örneği. Muhasebe ve Finansman Dergisi, 41, 156-170.

DOĞAN, Z. (2013). Borsa İstanbul'da İşlem Gören Firmaların Türev Araç Kullanımını Etkileyen Faktörler. Türkiye Odalar ve Borsalar Birliği (TOBB) Ekonomi ve Teknoloji Üniversitesi Sosyal Bilimler Enstitüsü Yayımlanmamış Yüksek Lisans Tezi, Ankara.

DURMUŞ, Ö. (2016). Türev Ürün Kullanımını Belirleyen Faktörler: Borsa İstanbul Üzerine Bir Uygulama. Pamukkale Üniversitesi Sosyal Bilimler Enstitüsü Yayımlanmamış Yüksek Lisans Tezi, Denizli.

DURMUŞ, Ö. ve COŞKUN, E. (2019). Şirketlerin Türev Ürün Kullanımını Etkileyen Faktörler: Borsa İstanbul'da Bir Araştırma. Çankırı Karatekin Üniversitesi İktisadi ve İdari Bilimler Fakültesi Dergisi, 9(2), 507-534.

DÜNDAR, R. Z. (2011). Riskten Korunma Amaçlı Türev Ürün Kullanımını Belirleyenler ve İMKB 30 İçin Bir Uygulama. İstanbul Teknik Üniversitesi Sosyal Bilimler Enstitüsü Yayımlanmamış Yüksek Lisans Tezi, İstanbul.

EFEOĞLU, M. (2018). Ticari İşletmelerde Türev Araçların Kullanımının Finansal Performansa Etkisi. Adnan Menderes Üniversitesi Sosyal Bilimler Enstitüsü Yayımlanmamış Yüksek Lisans Tezi, Aydın.

ERDOĞAN, S. ve BOZKURT, H. (2008). Türkiye'de Yaşam Beklentisi - Ekonomik Büyüme İlişkisi: ARDL Modeli İle Bir Analiz. Bilgi Ekonomisi ve Yönetimi Dergisi, 3(1), 25-38.

FETTAHOĞLU, S., İNAL, M. ve YAŞAR, H. (2018). Türev Ürün Kullanımının Banka Etkinliği İle İlişkisinin Belirlenmesine Yönelik Bir Çalışma. Verimlilik Dergisi, 2, 99-113.

GOLDBERG, S. R., GODWIN, J. H., KIM, M. S. ve TRITSCHER, C. A. (1998). On the Determinants of Corporate Usage of Financial Derivatives. Journal of International Financial Management and Accounting, 9(2), 132-166

GÜNGÖR, K. (2017). Türkiye'deki Şirketlerin Türev Araç Kullanım ve Miktarını Belirleyen Faktörlerin İncelenmesi: Borsa İstanbul Örneği. Türkiye Odalar ve Borsalar Birliği (TOBB) Ekonomi ve Teknoloji Üniversitesi Sosyal Bilimler Enstitüsü Yayımlanmamış Yüksek Lisans Tezi, Ankara.

GÜVEN, B. (2019). İşletmelerde Türev Ürün Kullanımını Açıklayan Modellerin Karşılaştırılması Üzerine Bir Araştırma. Marmara Üniversitesi Sosyal Bilimler Enstitüsü Yayımlanmamış Yüksek Lisans Tezi, İstanbul.

HASSAN, M. K. ve KHASAWNEH, A. (2009). The Determinants of Derivatives Activities in U.S. Commercial Banks. Indiana State University Working Paper, 9, 1-26.

HUNDMAN, K. (1999). An Analysis of the Determinants of Financial Derivative Use By Commercial Banks. The Park Place Economist, 7(1), 82-92.

KHAN, I. ve ARIF, H. ve TAHIR, M. (2018). The Use and Determinants of Derivatives: Empirical Evidence from Banking Sector of Pakistan. Journal of Managerial Sciences, 12(1), 63-74.

KIM, M., KIM, G. R. ve KIM, M. (2004). Stock Market Volatility and Trading Activities in the KOSPI 200 Derivatives Markets. Applied Economics Letters, 11, 49-53.

KOUSER, R., MAHMOOD, Z., BANO, T. ve AAMIR, M. (2016). Determinants of Financial Derivatives Usage: A Case of Financial Sector of Pakistan. Pakistan Journal of Social Sciences, 36(2), 641-652.

KUZU, S. ve ÇELIK, İ. E. (2019). Türk Bankacılık Sektöründe Türev Ürün Kullanımda Etkili Olan Faktörlerin Analizi. Turkish Studies - Social Sciences, 14(5), 2303-2323. 
KWIATKOWSKI, D., PHILlIPS, P. C., SCHMIDT, P. ve SHIN, Y. (1992). Testing The Null Hypothesis of Stationarity Against the Alternative of a Unit Root. Journal of Econometrics, 54, 159-178.

MACKINNON, J. G. (1996). Numerical Distribution Functions for Unit Root and Cointegration Tests. Journal of Applied Econometrics, 11, 601-618.

NIETO, M. L., FERNANDEZ, A., MUNOZ (1998). Market Efficiency in the Spanish Derivatives Markets: An Empirical Analysis. International Advances in Economic Research, 4, 349-355.

OKTAR, S. ve YÜKSEL, S. (2016). Bankaların Türev Ürün Kullanımını Etkileyen Faktörler: Mars Yöntemi İle Bir İnceleme. Finans Politik \& Ekonomik Yorumlar, 53(620), 31-46.

ÖZGÜMÜŞ, H., KORKMAZ, T. ve ÇEVİK, E. İ. (2013). Makroekonomik Faktörlerin Vadeli İşlem (Futures) Sözleşmelerine Etkisi: VOB’ta Bir Uygulama. Bankacılık Denetleme ve Düzenleme Kurulu Bankacılık ve Finansal Piyasalar, 7(1), 103-136.

PESARAN, M. H., SHIN, Y. ve SMITH, R .J. (2001). Bounds Testing Approach to the Analysis of Level Relationships. Journal of Applied Econometrics, 16 (3), 289-326.

PESERAN, M. H. ve SHIN, Y. (1997). An Autoregressive Distributed Lag Modelling Approach to Cointegration Analysis. Symposium at the Centennial of Ragnar Frisch.

PUMANANDAM, A. (2007). Interest Rate Derivatives at Commercial Banks: An Empirical İnvestigation. Journal of Monetary Economics, 54, 1769-1808.

RIVAS, A., OZUNO, T. ve POLICASTRO, F. (2006). Does The Use of Derivatives Increase Bank Efficiency? Evidence From Latin American Banks, International Business \& Economics Research Journal, 5(11), 47-56.

SEFERTAŞ, N. (2020). Türev Ürünlerin Banka Mali Tablolarına Etkileri. Marmara Üniversitesi Sosyal Bilimler Enstitüsü Yayımlanmamış Yüksek Lisans Tezi, İstanbul.

SHIU, Y. M. (2007). An Empirical Investigation on Derivatives Usage: Evidence from the United Kingdom General Insurance Industry. Applied Economics Letters, 14(5), 353-360.

ŞIMŞEK, K. Ç. (2015). Türk Bankacılık Sektörü Kur Riski Yönetiminde Türev Ürünler: Döviz Swap İşlemleri İle Makroekonomik Faktörler Arasındaki İlişki. Üçüncü Sektör Sosyal Ekonomi, 50(2), 723-101.

ŞİRVAN, N. ve ALP, Ö. S. (2017). Türev Piyasa Araçlarının Türk Bankacılık Sektöründe Riske Olan Etkileri. Başkent Üniversitesi Ticari Bilimler Fakültesi Dergisi, 1(1), 130-157.

TAKAO, A. ve LANTARA, W. N. (2010). The Determinants of the Use of Derivatives In Japanese Insurance Companies. SSRN Electronic Journal, 1-15.

TANRIÖVEN, C. ve YENICE, S. (2014). Bankaların Türev Araç Kullanımlarının Risklilik ve Karlılık Üzerine Etkisi - Türkiye Örneği. Gazi Üniversitesi İktisadi ve İdari Bilimler Fakültesi Dergisi, 16(3), 25-46.

TAŞTEMEL, G. (2020). Türkiye'deki Bankaların Türev Ürün Kullanım Yoğunluğu. Girişimcilik ve Kalkınma Dergisi, 15(1), 37-60.

TCMB EVDS (2021). Türkiye Cumhuriyet Merkez Bankası Elektronik Veri Dağıtım Sistemi. https://evds2.tcmb.gov.tr, 23.05.2021.

YALÇIN, C. Ç. (2015). Türk Bankacılık Sektöründe Türev Ürünler ve Türev Ürünlerin Kullanımını Etkileyen Faktörlerin Analizi. Gazi Üniversitesi Sosyal Bilimler Enstitüsü Yayımlanmamış Yüksek Lisans Tezi, Ankara. 